\title{
Effects of Plastic Mulch Types on Crop Performance of Drip Irrigated Winter and Summer Peppers ${ }^{1}$
}

\author{
Megh R. Goyal, Rubén Guadalupe Luna, Luis E. Rivera and \\ E. R. de Hernández ${ }^{2}$
}

\begin{abstract}
Plant growth, yield, fruit quality and fruit performance characteristics were evaluated for transparent (T1)-, white (T2)-, black (T3)-, silver coated black plastic (T4) mulched, organic mulched, (T5) and non-mulched (T6) peppers (var. Cubanelle) under drip irrigation during winter and summer of 1981-82. Values of plant growth parameters, fruit weight, fruit width and length were significantly higher at $5 \%$ level during the winter than during the summer in each treatment thus resulting in increased winter pepper yield. T1 plots caused lowest pepper yield at 5\% compared to yield of T2, T3, T4, T5 and T6. The percentage of defective peppers was highest at $5 \%$ level during the summer than during the winter. Second harvest had highest fruit weight at $5 \%$ level in comparison with third and fourth harvests during the winter and summer.
\end{abstract}

\section{INTRODUCTION}

Separation of products into various grades on the basis of quality and size is the greatest stimulus to better methods of marketing because this grading helps growers to pool their products in cooperative marketing associations in order to share equitably in the season's sales. Any variation in appearance, texture, taste and other physical characteristics usually make a difference in the selling price of produce. To what extent USDA grading standards are applicable to vegetables grown in Puerto Rico remains to be determined. About $83 \%$ of total vegetable consumption in Puerto Rico is imported. Local demand for vegetable products and fresh vegetables (5) as well as the interest of local industry in marketing fresh vegetables, is increasing.

Albergts and Howard (1) reported that the size and number of pepper fruits per plant were increased by mulch treatment. Early growth and marketable yield of pepper were greatest with full bed mulch $(1,5,6,8$, $10,11)$. Aluminum foil mulch contributes to few virus symptoms in peppers $(2,5,7)$ and increased vegetative growth $(3,5,11)$. Priester (9) has outlined guidelines for grading of Cubanelle peppers.

A study to determine the possibility of using different plastic mulches

${ }^{1}$ Manuscript submitted to Editorial Board August 29, 1983.

This study was conducted under H326(S-143), Southern Region Research Project"Trickle Irrigation in Humid Regions" and H-284, "Grading of Vegetables".

${ }^{2}$ Associate Agricultural Engineer, Associate Horticulturist, Research Assistant, and Assistant Food Technologist, respectively, Agricultural Experiment Station, University of Puerto Rico, Mayagüez Campus, Río Piedras, PR. 
for pepper production was conducted at the Fortuna Agricultural Research and Development Center, located on the semiarid southern coast of Puerto Rico. The soil belongs to the San Antón series with a pH of 7.9. The conductivity of the soil solution is $0.04 \mathrm{mmhos}$ per $\mathrm{cm}$.

The objectives of this study were to evaluate effects of transparent-, white-, black-, silver-coated black plastic mulches, organic mulch and non-mulching on commerical yield, plant growth, and fruit quality of drip irrigated winter and summer peppers (var. Cubanelle) during 198182.

\section{MATERIALS AND METHODS}

A drip irrigation system described by Goyal (4) was used in this study. Laterals of dual chamber drip tubing (chapin $14 \mathrm{mil}$ ) with $0.76 \mathrm{~mm}$ orifices spaced $60 \mathrm{~cm}$ apart were placed $1.8 \mathrm{~m}$ apart to supply the water to the plants at $55-69 \mathrm{kPa}\left(8-10 \mathrm{lb} / \mathrm{in}^{2}\right)$. Layflat tubing was used for main and submains. All irrigation materials were placed on the soil surface. Beds were shaped with a bed shaper on $1.8 \mathrm{~m}$ spacing. The plastic mulch ( $0.038 \mathrm{~mm}$ thick) and organic mulch were manually placed over the desired beds. Holes were punched in the plastic with a $5 \mathrm{~m}$ pipe at the desired locations. Each plot had 5 beds with outer beds for border.

Summer and winter peppers (var. Cubanelle) were subjected to four plastic mulch types (transparent $=\mathrm{T} 1$, White $=\mathrm{T} 2$, black $=\mathrm{T} 3$, and silver coated black $=\mathrm{T} 4)$, organic mulch $(=\mathrm{T} 5)$ and control $(=\mathrm{T} 6)$ with 4 replications. Irrigation was based upon readings of tensiometers installed at $15 \mathrm{~cm}$ depth in the non-mulched plots. The irrigation was applied when the soil moisture tension, as measured by tensiometers, was 45 cbars. Irrigation was terminated when the moisture tension dropped to 15 cbars. Fungicides and insecticides were applied as needed according to package practices for vegetables by the Agricultural Experiment Station.

\section{PEPPER (WINTER)}

Maximum and minimum air temperatures (fig. 1) during the crop season were 32.2 and $15^{\circ} \mathrm{C}$. The seasonal precipitation and class A pan evaporation (fig. 1) were 204.2 and $601.8 \mathrm{~mm}$, respectively. Pepper transplants (date of planting in nursery, Nov. 3, 1981) were transplanted December 5, 1981 on both sides of drip lines in a zigzag pattern at a distance of $15 \mathrm{~cm}$ away from the drip line. Plant spacing was $30 \mathrm{~cm}$ down the row. The dead spots were retransplanted the 9th day. Fertigation ${ }^{3}$ $\left(\mathrm{KNO}_{3}\right.$ and $\mathrm{H}_{3} \mathrm{PO} 4$ ) was on the $13,18,31,39,44,51,59,69$, and 81st day after transplanting. The peppers were manually harvested on the 51 th,

\footnotetext{
${ }^{3}$ Fertigation is the application of fertilizers via the irrigation system.
} 

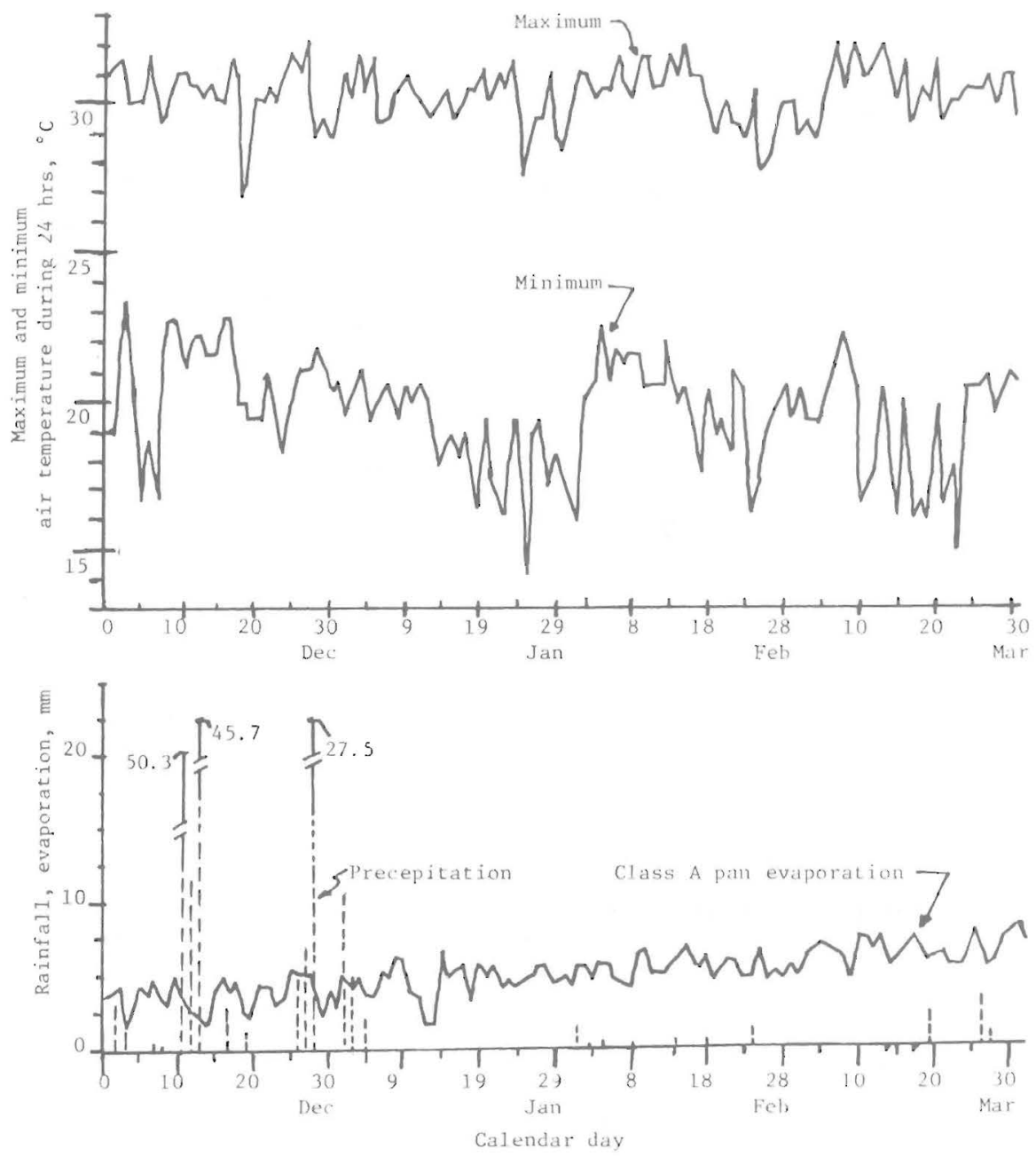

FIG. 1.-Climatic data for drip irrigated winter peppers, 1981-82.

68th, 88th, 104th and 130th day. The last picking was on April 1, 1982. Fifty peppers were sampled on the 68th, 88th and 104th day and were transferred to Food Technology Laboratory. The samples from each treatment were evaluated for pepper length, pepper width and pepper weight. The percentage of diseased and damaged peppers (9) were also recorded in each plot. On the 130 th day, 10 plants per plot were cut and were evaluated for plant height, fresh and dry plant weight, number of secondary and tertiary branches, and stem diameter at $1.3 \mathrm{~cm}$ from the root base. 
PEPPER (SUMMER)

Maximum and minimum air temperatures (fig. 2) during the crop season were 33.4 and $15.0^{\circ} \mathrm{C}$. The precipitation and class A pan evaporation (fig. 2) were 282.4 and $720.3 \mathrm{~mm}$, respectively. Pepper transplants (date of planting in nursery: February 12,1982) were transplanted March 17, 1982. Dead spots were retransplanted on the 5th day. Fertigation was on the 33rd, 44th, 69th, 79th, 86th, 93rd, 99th and 105th day. Peppers were manually harvested on the $64 \mathrm{th}, 84 \mathrm{th}, 105 \mathrm{th}$ and $125 \mathrm{th}$ day. Last
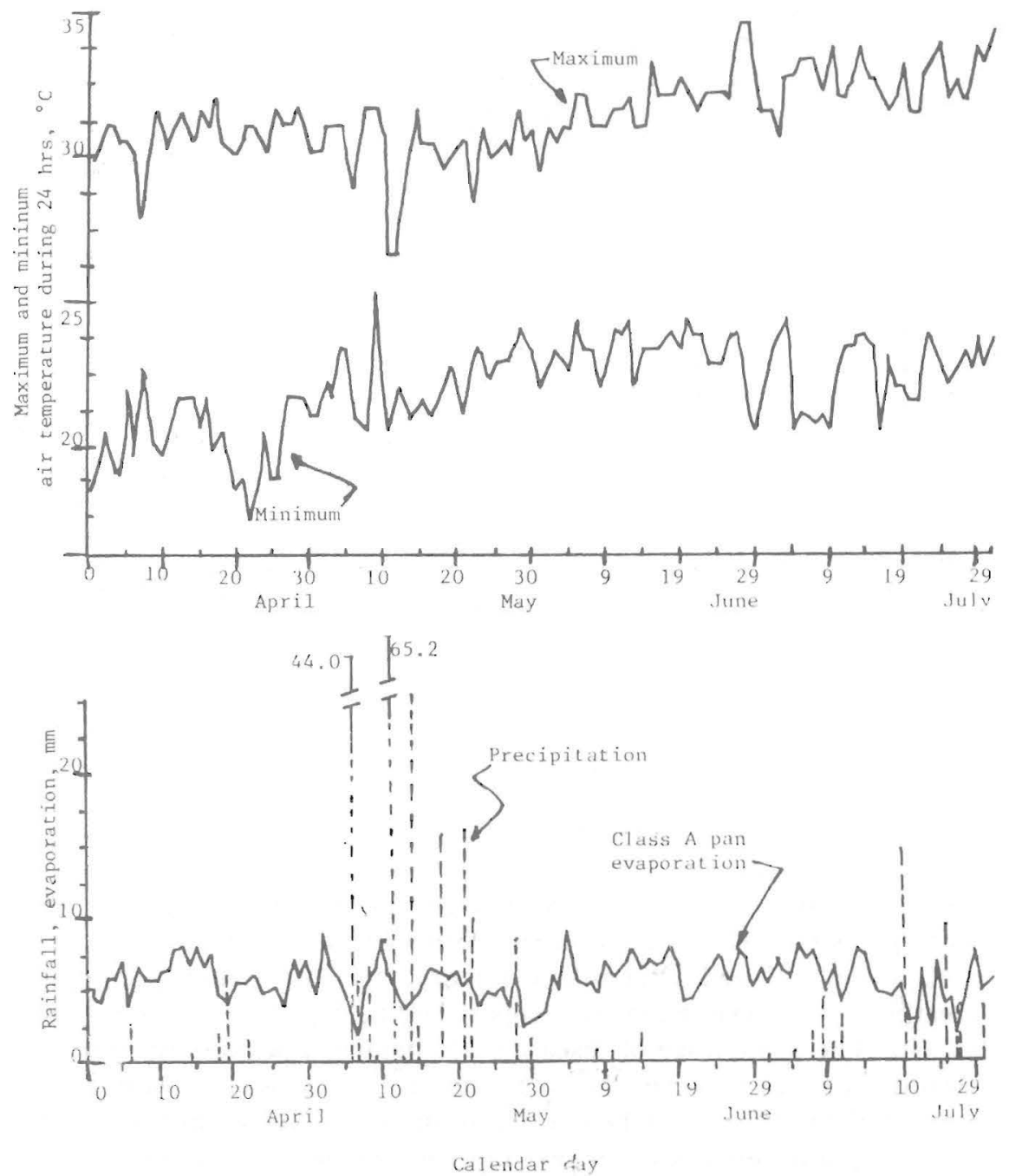

FIG. 2.-Climatic data for drip irrigated summer peppers, 1981-82. 
picking was July 20, 1982. Fifty peppers were sampled on the 64 th, 84 th and 105th day and were evaluated for pepper length, width, weight, and percent defect (9) by the Food Technology Laboratory. On the 125th day, 10 plants per plot were removed to evaluate final plant height, fresh and dry plant weight, number of branches, and trunk diameter at $1.3 \mathrm{~cm}$ from the root base.

\section{RESULTS AND DISCUSSION}

Table 1 shows effects of transparent (T1)-, white (T2)-, black (T3)-, silver coated black (T4)- plastic mulches, organic mulch (T5) and control (T6) on commercial pepper yield, final plant height, number of branches, stem diameter of dry plant, fresh and dry plant weight, and percentage moisture per plant at the last picking. Crop yield was higher in winter than in the summer; these differences were significant at the $1 \%$ level in all the treatments except in T2. Treatment T4 yielded 41.9 tons/ha of commerical peppers compared with $32.7,32.4,31.9,29.9$ and 28.8 tons/ ha in the T6, T2, T3, T5 and T1 plots, respectively and was significantly highest at the $5 \%$ level compared with yields of T1, T2, T3, T5 and T6, during the winter. Crop yield was $12.5,26.3,23.3,25.3,17.9$, and 24.3 tons/ha in the T1, T2, T3, T4, T5 and T6 plots, respectively during the summer. Treatment $\mathrm{T} 1$ had the lowest yield, significant at the $5 \%$ level compared to $\mathrm{T} 4$. The differences among the other treatments were not significant. Final plant height was not significantly different in all the treatments in winter, whereas $\mathrm{T} 1$ had the lowest plant height at the $5 \%$ level compared to other treatments during the summer. T1 plants were significantly higher ( $1 \%$ level) in winter than in summer. The number of branches per plant were lowest in T1 compared to other treatments in winter and in summer. T3 had the highest number of branches in winter and in summer. In winter, T3 plants had the thickest stem, significant at the $5 \%$ level compared with those of $\mathrm{T} 1$ and T6. During the summer, T1 plants had the thinnest stem, significant at the $1 \%$ level compared to those of T2, T3, T4, T5 plants. Stem in T6 was significantly thinner at the 5\% level than those of T2, T3, T4, T5 plants. Stem thickness did not differ significantly at the $5 \%$ level between summer and winter in each treatment. During the winter, fresh and dry plant weight were significantly highest in $\mathrm{T} 5$ compared with those of $\mathrm{T} 1$ at the $1 \%$ level and with those of T3 at the 5\% level. T1 plants had the lowest fresh and dry weights at the $1 \%$ compared to those of $\mathrm{T} 2, \mathrm{~T} 3, \mathrm{~T} 4, \mathrm{~T} 5$ plants in summer. The fresh and dry weights in winter were significantly higher at the $5 \%$ level than in summer in treatments T1 and T6. The differences were not significant in the other treatments. Plant moisture percentage (dry basis) in winter was significantly higher at the $5 \%$ level than in summer in the T3, T5 and T6 treatments. 
TABLE 1.-Effects of mulch types on commercial pepper yield, plant height and number of branches in trickle irrigated summer and winter peppers, 1981-82

\begin{tabular}{|c|c|c|c|c|c|c|c|c|}
\hline \multirow[b]{2}{*}{$\begin{array}{l}\text { Mulch } \\
\text { type }^{5}\end{array}$} & \multicolumn{8}{|c|}{ Crop performance ${ }^{1}$} \\
\hline & $\begin{array}{l}\text { Pepper } \\
\text { yield }\end{array}$ & $\begin{array}{l}\text { Plant } \\
\text { height }\end{array}$ & $\begin{array}{c}\text { No. }{ }^{2} \text { of } \\
\text { branches }\end{array}$ & $\begin{array}{c}\text { Trunk }^{2} \\
\text { diameter } \\
\text { dry plant }\end{array}$ & $\begin{array}{l}\text { Fresh } \\
\text { plant } \\
\text { weight }^{2}\end{array}$ & $\begin{array}{c}\text { Dry } \\
\text { plant } \\
\text { weight }{ }^{2}\end{array}$ & Moisture $^{2}$ & Moisture $^{2}$ \\
\hline & g/hectare & $\mathrm{cm}$ & & $\mathrm{cm}$ & $g$ & $g$ & $g$ & $\%$ \\
\hline \multicolumn{9}{|c|}{ Winter peppers ${ }^{3}$} \\
\hline $\mathrm{TP}$ & $28775.7 \mathrm{~b}$ & $71.6 \mathrm{a}$ & $43 \mathrm{ac}$ & $1.2 \mathrm{bc}$ & $207.8 \mathrm{ac}$ & $48.4 \mathrm{ac}$ & $159.4 \mathrm{~b}$ & $332.5 \mathrm{a}$ \\
\hline WP & $32469.1 b$ & $68.4 \mathrm{a}$ & $53 \mathrm{ac}$ & $1.3 \mathrm{ac}$ & $278.4 \mathrm{bc}$ & $60.2 \mathrm{bc}$ & $205.7 \mathrm{bc}$ & $378.7 \mathrm{a}$ \\
\hline $\mathrm{BP}$ & $31923.8 b$ & $69.6 \mathrm{a}$ & $58 b$ & $1.4 \mathrm{ac}$ & $241.8 \mathrm{ac}$ & $53.5 \mathrm{ac}$ & $188.3 \mathrm{bc}$ & $351.4 \mathrm{a}$ \\
\hline SCBP & $41903.3 \mathrm{a}$ & $70.2 \mathrm{a}$ & $56 b c$ & $1.4 \mathrm{ac}$ & $296.9 \mathrm{bc}$ & $67.2 \mathrm{bc}$ & $229.8 \mathrm{ac}$ & $338.1 \mathrm{a}$ \\
\hline OM & 29999.5b & $68.4 \mathrm{a}$ & $56 \mathrm{ac}$ & $1.5 \mathrm{a}$ & $363.9 \mathrm{~b}$ & $78.2 \mathrm{~b}$ & $285.8 \mathrm{a}$ & $364.5 \mathrm{a}$ \\
\hline NM & $32736.6 b$ & $67.0 \mathrm{a}$ & $47 a$ & $1.4 \mathrm{ac}$ & $279.6 \mathrm{bc}$ & $62.2 \mathrm{bc}$ & $217.4 \mathrm{abc}$ & $351.6 \mathrm{a}$ \\
\hline \multicolumn{9}{|c|}{ Summer peppers ${ }^{4}$} \\
\hline $\mathrm{TP}$ & $12515.4 \mathrm{ac}$ & $51.9 a$ & $35 \mathrm{a}$ & $0.9 \mathrm{~b}$ & $104.5 \mathrm{~b}$ & $28.1 b$ & $76.5 \mathrm{~b}$ & $275.4 \mathrm{bc}$ \\
\hline WP & $26327.1 \mathrm{bc}$ & $67.3 \mathrm{~b}$ & $68 \mathrm{~b}$ & $1.3 \mathrm{a}$ & $244.2 \mathrm{a}$ & $59.3 \mathrm{ac}$ & $184.8 \mathrm{a}$ & $318.3 \mathrm{ac}$ \\
\hline $\mathrm{BP}$ & $23325.6 \mathrm{bc}$ & $68.8 \mathrm{~b}$ & $75 b$ & $1.4 \mathrm{a}$ & $251.1 \mathrm{a}$ & $61.8 \mathrm{ac}$ & $189.3 \mathrm{a}$ & $305.9 \mathrm{abc}$ \\
\hline SCBP & $25285.5 b$ & $71.5 \mathrm{~b}$ & $74 \mathrm{~b}$ & $1.5 \mathrm{a}$ & $290.3 \mathrm{a}$ & $68.9 \mathrm{a}$ & $221.4 \mathrm{a}$ & $319.5 a$ \\
\hline $\mathrm{OM}$ & $17870.3 \mathrm{bc}$ & $57.4 \mathrm{~b}$ & $66 \mathrm{~b}$ & $1.4 \mathrm{a}$ & $282.1 \mathrm{a}$ & $69.3 \mathrm{a}$ & $212.8 \mathrm{a}$ & $304.2 \mathrm{abc}$ \\
\hline NM & $24251.5 \mathrm{bc}$ & $64.8 \mathrm{~b}$ & $54 a$ & $1.2 \mathrm{~b}$ & $173.2 \mathrm{~b}$ & $45.6 \mathrm{c}$ & $127.6 \mathrm{~b}$ & $280.5 b$ \\
\hline
\end{tabular}

${ }^{1}$ Means followed by one or more letters in common do not differ significantly at the $5 \%$ level by Duncan's multiple range test. Each data is the mean of 12 observations.

${ }^{2}$ At last picking.

${ }^{3}$ Date of transplanting: December 5, 1981. Date of last picking: April 1, 1982.

${ }^{4}$ Date of transplanting: March 17, 1982. Date of last picking: July 20, 1982.

${ }^{5} \mathrm{TP}=$ Transparent plastic; $\mathrm{WP}=$ White Plastic; $\mathrm{BP}=$ Black plastic; $\mathrm{SCBP}=$ Silver coated black plastic; $\mathrm{OM}=\mathrm{Organic}$ mulch; $\mathrm{NM}=$ 
Table 2 indicates effects of treatments T1, T2, T3, T4, T5 and T6 on pepper length, width, weight, and percentage of defective peppers in winter and summer for three pickings. Differences among the treatments were not significant at the $5 \%$ level in case of percentage of defective peppers in summer and winter. The percentage of defective peppers was highest at the $5 \%$ level in summer than in winter in all three harvestings.

During the winter, pepper weight was lowest in the fourth picking compared to that of second and third pickings; the differences were significant at the $5 \%$ level in treatments $\mathrm{T} 1, \mathrm{~T} 2, \mathrm{~T} 3, \mathrm{~T} 4$ and $\mathrm{T} 6$. There was a significant difference at the $5 \%$ level between the second and fourth pickings in T5. The second picking yielded the longest peppers at the $5 \%$ level compared with those of the third and fourth pickings in all the treatments except $\mathrm{T} 5$. The third picking yielded the longest peppers at the $5 \%$ level compared with those of the second and fourth pickings in T5. Pepper width was smallest at the $5 \%$ level in the fourth picking compared to the second and third pickings in $\mathrm{T} 1, \mathrm{~T} 3$, T4 and $\mathrm{T} 6$. In treatments $\mathrm{T} 2$ and $\mathrm{T} 5$, the second picking yielded the widest peppers compared with the fourth picking at the $5 \%$ level. There was no significant difference at the $5 \%$ level among the treatments in fruit weight and fruit length in the second and fourth pickings. The differences among the treatments were not significant at the $5 \%$ level in case of fruit length in the third picking and in case of fruit width in the fourth picking. Fruit weight was significantly less in the $\mathrm{T} 1$ at the $5 \%$ level compared to $\mathrm{T} 4$ and T6 in the third picking. Peppers were thinner in T5 at the 5\% level compared to T3 in the second picking; and in T6 they were thinnest at the $5 \%$ level compared to those of $\mathrm{T} 3$ and $\mathrm{T} 4$ in the third picking.

During the summer, the differences among the treatments were not significant at the $5 \%$ level in case of fruit width for all pickings; fruit length for the second and fourth pickings; and fruit weight for the third, respectively. Fruit weight was lowest at the $5 \%$ level in the T1 compared to $\mathrm{T} 2$ in the second picking; T3 peppers were heavier at the $5 \%$ level compared with T2 and T6 peppers in the fourth picking. Fruit length was shortest at the 5\% level in T5 compared with T1 in the third picking. The values of fruit parameters were higher during winter compared with those in the summer on respective pickings. This caused significantly higher pepper yield in winter (table 1).

\section{RESUMEN}

Se evaluó el crecimiento, rendimiento, calidad y características de desarrollo de pimientos (var. Cubanelle) en los tratamientos de cubierta transparente (T1), blanca (T2), negra (T3), plateada (T4), orgánica (T5) y sin cubierta (T6) regados por goteo durante el invierno y verano 1981-82. En todos los tratamientos los pimientos fueron significativamente $(5 \%)$ 
TABLE 2.-Effects of mulch types on fruit performance of trickle irrigated winter and summer peppers, 1981-82

\begin{tabular}{|c|c|c|c|c|c|}
\hline \multirow{2}{*}{$\begin{array}{c}\text { Sampling } \\
\text { date }\end{array}$} & \multirow{2}{*}{$\begin{array}{l}\text { Mulch } \\
\text { type }^{1}\end{array}$} & \multicolumn{4}{|c|}{ Fruit performance, per pepper } \\
\hline & & $\begin{array}{c}\% \\
\text { defective }^{2}\end{array}$ & $\begin{array}{c}\text { Weight } \\
\mathrm{g}^{3}\end{array}$ & $\begin{array}{l}\text { Length } \\
\mathrm{cm}^{3}\end{array}$ & $\begin{array}{c}\text { Width } \\
\mathrm{cm}^{3}\end{array}$ \\
\hline \multicolumn{6}{|c|}{ Winter peppers ${ }^{4}$} \\
\hline Feb 11, 1982 & $\mathrm{TP}$ & 16.5 & $64.1 \mathrm{a}$ & $12.5 \mathrm{a}$ & $4.9 \mathrm{bc}$ \\
\hline \multirow[t]{5}{*}{ (2nd harvest) } & WP & 20.0 & $59.8 \mathrm{a}$ & $12.5 \mathrm{a}$ & $4.6 \mathrm{bc}$ \\
\hline & $\mathrm{BP}$ & 17.3 & $60.4 \mathrm{a}$ & $11.8 \mathrm{a}$ & $4.8 \mathrm{~b}$ \\
\hline & SCBP & 17.5 & $65.3 \mathrm{a}$ & $12.2 \mathrm{a}$ & $4.9 \mathrm{bc}$ \\
\hline & $\mathrm{OM}$ & 19.0 & $53.4 \mathrm{a}$ & $11.4 \mathrm{a}$ & $4.5 \mathrm{ac}$ \\
\hline & NM & 19.0 & $63.1 \mathrm{a}$ & $12.2 \mathrm{a}$ & $4.8 \mathrm{bc}$ \\
\hline \multirow{6}{*}{$\begin{array}{l}\text { March } 02,82 \\
\quad \text { (3rd harvest) }\end{array}$} & $\mathrm{TP}$ & 17.5 & $54.9 \mathrm{ac}$ & $11.3 \mathrm{a}$ & $4.8 \mathrm{bc}$ \\
\hline & WP & 16.5 & $55.7 \mathrm{bc}$ & $11.3 \mathrm{a}$ & $4.8 \mathrm{bc}$ \\
\hline & $\mathrm{BP}$ & 13.5 & $55.8 \mathrm{bc}$ & $11.2 \mathrm{a}$ & $4.8 \mathrm{~b}$ \\
\hline & SCBP & 14.8 & $60.1 \mathrm{~b}$ & $11.1 \mathrm{a}$ & $5.0 \mathrm{~b}$ \\
\hline & $\mathrm{OM}$ & 15.5 & $55.2 \mathrm{bc}$ & $10.7 \mathrm{a}$ & $4.8 \mathrm{bc}$ \\
\hline & NM & 15.5 & $58.9 b$ & $11.3 \mathrm{a}$ & $4.7 \mathrm{ac}$ \\
\hline \multirow{7}{*}{$\begin{array}{l}\text { March } 18,82 \\
\text { (4th harvest) }\end{array}$} & $\mathrm{TP}$ & 17.8 & $48.3 \mathrm{a}$ & $11.4 \mathrm{a}$ & $4.4 \mathrm{a}$ \\
\hline & WP & 17.8 & $45.4 \mathrm{a}$ & $11.1 \mathrm{a}$ & $4.2 \mathrm{a}$ \\
\hline & $\mathrm{BP}$ & 17.8 & $47.9 \mathrm{a}$ & $11.1 \mathrm{a}$ & $4.4 \mathrm{a}$ \\
\hline & SCBP & 15.5 & $49.0 \mathrm{a}$ & $11.2 \mathrm{a}$ & $4.4 \mathrm{a}$ \\
\hline & $\mathrm{OM}$ & 15.5 & $46.2 \mathrm{a}$ & $10.8 \mathrm{a}$ & $4.4 \mathrm{a}$ \\
\hline & NM & 16.5 & $44.9 \mathrm{a}$ & $11.0 \mathrm{a}$ & $4.3 \mathrm{a}$ \\
\hline & & Summer & $e r s^{5}$ & & \\
\hline \multirow{6}{*}{$\begin{array}{l}\text { May } 20,82 \\
\quad(2 \text { nd harvest) }\end{array}$} & $\mathrm{TP}$ & 22.8 & $38.3 \mathrm{ac}$ & $10.9 \mathrm{a}$ & $4.0 \mathrm{a}$ \\
\hline & WP & 21.5 & $47.1 b$ & $10.6 \mathrm{a}$ & $4.3 \mathrm{a}$ \\
\hline & $\mathrm{BP}$ & 25.0 & $47.6 \mathrm{bc}$ & $10.7 \mathrm{a}$ & $4.4 \mathrm{a}$ \\
\hline & SCBP & 17.8 & $47.0 \mathrm{bc}$ & $10.9 \mathrm{a}$ & $4.4 \mathrm{a}$ \\
\hline & $\mathrm{OM}$ & 24.8 & $42.3 \mathrm{bc}$ & $10.7 \mathrm{a}$ & $4.3 \mathrm{a}$ \\
\hline & NM & 20.8 & $45.1 \mathrm{bc}$ & $10.7 \mathrm{a}$ & $4.1 \mathrm{a}$ \\
\hline \multirow{7}{*}{$\begin{array}{l}\text { June 09, } 82 \\
\text { (3rd harvest) }\end{array}$} & TP & 26.3 & $31.6 \mathrm{a}$ & $10.1 \mathrm{ac}$ & $3.6 \mathrm{a}$ \\
\hline & WP & 32.3 & $28.7 \mathrm{a}$ & $9.5 b c$ & $3.3 \mathrm{a}$ \\
\hline & $\mathrm{BP}$ & 26.8 & $30.7 a$ & $9.7 \mathrm{bc}$ & $3.5 \mathrm{a}$ \\
\hline & SCBP & 25.5 & $33.2 \mathrm{a}$ & $9.9 b c$ & $3.8 \mathrm{a}$ \\
\hline & $\mathrm{OM}$ & 28.5 & $27.1 \mathrm{a}$ & $9.3 \mathrm{~b}$ & $3.4 \mathrm{a}$ \\
\hline & NM & 27.3 & $28.9 \mathrm{a}$ & $9.6 \mathrm{~b}$ & $3.4 \mathrm{a}$ \\
\hline & & Summer & $e r s^{5}$ & & \\
\hline \multirow{6}{*}{$\begin{array}{l}\text { July } 20,82 \\
\qquad \text { (4th harvest) }\end{array}$} & $\mathrm{TP}$ & 38.0 & $24.1 \mathrm{ac}$ & $9.5 \mathrm{a}$ & $2.9 \mathrm{a}$ \\
\hline & WP & 38.8 & $22.9 b c$ & $9.2 \mathrm{a}$ & $3.7 \mathrm{a}$ \\
\hline & $\mathrm{BP}$ & 38.3 & $26.6 \mathrm{a}$ & $9.7 \mathrm{a}$ & $3.1 \mathrm{a}$ \\
\hline & SCBP & 36.3 & $24.3 \mathrm{ac}$ & $9.8 \mathrm{a}$ & $3.2 \mathrm{a}$ \\
\hline & $\mathrm{OM}$ & 39.3 & $24.6 \mathrm{ac}$ & $9.5 \mathrm{a}$ & $3.0 \mathrm{a}$ \\
\hline & NM & 40.3 & $22.9 \mathrm{bc}$ & $9.1 \mathrm{a}$ & $2.9 \mathrm{a}$ \\
\hline
\end{tabular}

${ }^{1} \mathrm{TP}=$ Transparent plastic, $\mathrm{WP}=$ white plastic, $\mathrm{BP}=$ black plastic, $\mathrm{SCBP}=$ Silver coated black plastic, $\mathrm{OM}=$ Organic mulch and $\mathrm{NM}=$ No mulch.

${ }^{2}$ Based upon 100 peppers. Defective peppers included immature, misshapen, insect damaged, sunburned, and scarred.

${ }^{3}$ Average of 200 peppers. Means followed by one or more letters in common do not differ significantly at the $5 \%$ level by Duncan's multiple range test.

${ }^{4}$ Date of transplanting: Dec 5, 1981; date of last harvest: April 1, 82.

${ }^{5}$ Date of transplanting: March 17, 1982; date of last harvest: July $20,82$. 
más anchos, más largos y más pesados en invierno que en verano, por lo cual el rendimiento en invierno fue más elevado. A esto se atribuye el incremento en rendimiento de pimientos durante el inverno. El tratamiento T4 arrojó un rendimiento de 41.9 ton/ha de pimientos comerciales comparado con las $32.7,32.4,31.9,29.9$ y 28.8 ton/ha obtenidas en los tratamientos T6, T2, T3, T5 y T1, respectivamente durante el invierno; significativamente superior a nivel del 5\%. El rendimiento en los tratamientos T1, T2, T3, T4, T5 y T6 fue 12.5, 26.3, 23.3, 25.3, 17.9 y 24.3 ton/ha, respectivamente en el verano. El tratamiento $\mathrm{T} 1$ obtuvo el rendimiento más bajo a nivel del 5\% de significancia comparado con el del T4. El porcentaje de pimientos con defectos fue mayor a nivel de significancia del $5 \%$ en el verano en comparación con el de las tres cogidas en el invierno. En la segunda cogida se obtuvo el peso mayor de las frutas a nivel del $5 \%$ de significancia comparado con el de las tercera y cuarta cogidas tanto en invierno como en verano.

\section{LITERATURE CITED}

1. Albergts E.F. and C.M. Howard, 1973. Effects of fertilization and mulching with biodegradable polyethylene-coated paper on responses of okra and peppers, HortSci., 8: $36-8$.

2. Black, L.L. and L.H. Ralston, 1972. Aluminum foil mulch reduces virus infection of peppers, La. Agric 15 (4): 6-7.

3. Downes, J.D., R.D. Heslip and S. Honma, 1959. Effect of polyethylene mulches, starter solution and kind of transplant on yields of sweet peppers, Mich. Agric. Exp. Stn. Bull. 41: 641-47.

4. Guadalupe-Luna, R., M.R. Goyal, M. Cintrón, L.E. Rivera and M. del C. Prieto de López, 1983. Effects of water application rates, plastic mulch and staking on size arrangements of mature green tomatoes under drip irrigation. J. Agric. Univ. P.R. 67 (3): 293-302.

5. Hopen, H.J. and N.F. Oebker, 1976. Vegetable crop responses to synthetic mulchesan annotated bibliography. NAPA Technical Bulletin 1, National Agricultural Plastics Association, USA.

6. Oebker, N.F., Y. Barr and H.J. Hopen, 1974. Experiences in mulching peppers and lettuce, HortSci. 9 (2):158.

7. — F. Harper and A.D. Halderman, 1973. Plastics and early pepper production in Arizona, Proc. Nat. Agric. Plast. Conf. 11: 200-09.

8. Ploper, J., 1968. Response of tomatoes, peppers and green beans under polyethylene in Tucumán, Argentina, Proc. Nat. Agric. Plast. Conf., 8: 130-36.

9. Priester, D.L., 1980. US standards for grades of Cubanelle peppers. Fresh Products Branch-Food Safety and Quality Service, USDA. June, 1980.

10. Smith, N.J., A. Brown Jr. and S. Race, 1973. Pepper production on reflective foil mulches, Proc. Nat. Agric. Plast. Conf., 11:193-99.

11. Thompson, H.C. and H. Platenius, 1932. Results of paper mulch experiments with vegetable crops, Proc. Am. Soc. Hortic. Sci., 28: 305-08. 